\title{
TWO CASES OF MICROCEPHALIC IDIOTCY IN ONE FAMHLY - CONVULSIONS OF MOTHER DURING PREGNANCY.
}

\author{
BY HERBEBT R. O. BANKEY, M.B. LOND.,

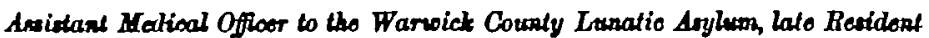 \\ Modioal Officor to the National Hospital for the Paralysod and Epileptio.
}

By the kindness of Dr. Parsey, I am permitted to describe the two following cases of microcephalic idiotcy at present under his care. I am aware that, without post-mortem examination, a description of these cases mnst of necessity be very imperfect. Since, however, many years may not improbably elapse before such an examination could bo made, I venture to publish the following clinical record, in the hope that it may be found to contain some points of interest.

Anne G., æt. 19 years, and Emily G., æt. 11 years, two sisters, were sdmitted into the Warwick County Lunatic Asylum in the years 1870 and 1872 respectively.

The family history, the greater part of which was obtained from their mother, is as follows:-

The patients' paternal grandparents were first cousins. 'Their father, who is a shoomaker by trade, also married his cousin. He is described as a sickly-looking man, of a nervous temperament, and is said not to be possessed of the average degree of intelligence. The mother also is a moman of no great mental activity. Neither parent has any insane relations; the youngest child, however, is, in all probability, like the two patients, a microcephalic idiot, but no other members of the family are idiotic ; there is, however, a strongly narked family tendency to hysteria and nervous irritability generally. The mother suffered from fits during certain of her pregnancies, and, as will be seen from the following account, her convulsions bear an interesting relation to the idiotcy of her children.

During her first pregnancy Mrs. G. had one slight fit. 
The child, however, though strumous, has not grown up yn idiut. While pregnant with her second child, the elder of the two patients, their mother suffered from severe epileptiform convulsions. The third pregnancy gave rise to a healthy child, and was not accompanied by fits, but during the gestrtion of Emily, the younger of the two patients, and the fourth child of the family, Mrs. G. again had fits. 'T'wo miscarriages then sucreeded, and then four children were born, who, though weakly, were not idiotic, no convalsions occurring during these pregnancies. During the gestation of the youngest child, however, now only two years old, the mother again suffered from epileptiform. seizures. Though this child has not been examined, there is good reason to suppose that it is an idiot, since its mother says that it has a small head, and that it does not take notice, nor attempt to speak. Like others of the family it is physically a weakly child, and suffers from enlarged glauds about the neck, \&c. Nevertheless the mother seems positive that this child is more than ordinarily backward in the development of its mental faculties.

The parents are temperate people, they live in a small country town, and have always had sufficient food and clothing.

The father's brother died of phthisis, but no other members of the fumily are known to have suffered from that disease.

'The elder sister, Anne G., now 19 years of age, has always enjoyed good bodily health, though she has been an idiot from birth. She has never suffered from fits, nor had any serious illness. When admitted into the asylum she was 11 years of age. Her stature was at that time not below the average. Her limbs were well proportioned. Her head was remarkably sinull, but its dimensions were not recorded. All the cranial sutures were closed. Her mental condition appears at that time to have been very similar to its present state. Her general henlth was good. She ate welf, but was not able to feed herself. She was dirty in her habits, and passed her dejections without regard to time and place. 'Though spiteful at times, ler temper was then pretty good. She is described as lively, and was pleased at boing noticed.

With advancing years she became more irritable and morose in her temper. During the three years subsequent to her udmission she grew a little, but since the expiration of that time little or no growth has taken place. In 1873 her hend measured 14 in. in circumference.

During the next three years there seems to have beeu some slight advance in her mental condition. She learned to use articulate soumds, but not to speak intelligibly. She becamo however more spiteful and passionate. In her borlily con- 
dition there was 110 great change, except that in 1876 the eatamenia bucrme estrablished.

At the present time her height is $3 \mathrm{ft}$. $10 \mathrm{t}$ in. ; from leer habit of stwoping, however, she looks much shorter. She is rather stout, and weighs 63 lbs. She is still dirty in her habits, and ullows her saliva to run from her mouth. Her most striking f'enture is her small head. Her forehead slants backward, so much as to be nearly in a straight line with her very prominent nose. Her incisor teeth project considerably, her chin is small, and the cheek bones are high and wide-a combination of features which makes her expression resemble that of a beaver, or water rat. Her occiput is so small that it scarcely at all overhangs her neck posteriorly. The cranial sutures are all closed, and there are no inequalities to indicate their position, so that the share taken by each bone in the formation of the skull cannot be determined.

The occipital protuberance is not well marked. The occlpital bone appears at first sight as if it were tilted forward: so that the protuberance is raised to a point higher than normal. Below the most prominent part (Fig. I.) there is a depression about an inch in length, and half an inch wide, and a quarter in depth. But at this point the bone feels subcutaneous, and no ridge can be felt, nor can any ligamentous bund be distinguished, even on flexing the head to the utmost, extending to the protuberance from the spines of the vertebre. 'l'he following are the chief measurements of the head :-

Grentest circumforenco $14+$ in.

Greatest antero-posterior diameter : . : . . 4 4 "

Distance from onc auditory nentus over the vertex to the other 9 ",

Longest trangrerse diumcter

Distance from ruot of nose to most prominent point at occiput .

Transverse diameter at mastoid processers

Distanoe from auditory mentus to middle of brow

Do. do. to prominent point at occiput .

'Transverso diameter from zygomn to zyguma, from a point just nnterior to articulation of jaw.

Distance from chin to vertex

Her gait is peculiar ; at first sight it seems to resemble that of paralysis agituns, but on more careful examination it is seen to resemble it ouly in the fact that the body is bent forward, and that the patient frequently runs. 'The feet are stamped rather beavily upon the ground, and her legs are moved in a very slovenly manner, but there is no real festination, nor are the knees bent to an unusual degree. She carries her thorax much more forward than is natural, and the head is thrust forward, though the neck is extended so that a straw hat placed on the top of the head when she walks has its brim 
resting flat on her back. In fact, the position of her head is very like that of a quadruped.

Her movements are clumsy and, as a rule, slow: She takes a considerable time before, as it were, she decides upon performing any voluntary movement with her hands; and though she is quite capable of making rapid movements, she usually moves but slowly: for example, when the callipers were applied to her head for the purpose of measuring it she invariably raised her hand to remove the instrument, but so slowly did she, do this that there was generally ample time to adjust it to her head before she took hold of it. She will, however, clap her hands and shake them, when pleased, quite rapidly. In clapping her hands, however, I have noticed that she, unlike a healthy person, holds her two hands in different, and often in awkward, positions, so that the two palms do not meet in such a way as to produce a sound.

The patient spends most of her time in running about the wards and garden, rarely sitting down except at meals.

Her temper is now better than it was two or three years ago, but she is still passionate, and, when ihwarted, will kick and bite most violently. She cannot speak at all. The few articulate sounds she utters are meaningless. She, however, understands much that is said to her-much more, indeed, than would at first be supposed.

Some idea of her degree of intelligence can be gathered from the following incident: She was eating some sweets when the nurse said, "Go and fetch Maria (an epileptic idiot), and give her some too." She at once ran away - went out of the door of the ward, whirh she opened herself, and ran round the garden, in which there were at least twenty or thirty patients for the most part dressed alike. She went intu all the corners and looked everywhere where she thought Maria might be; not finding her in the garden, however, she came back to the ward, still searching, going first into an adjoining room. When she at last discovered her sitting on the floor, she pulled her up and pushed her to the table, and put a sweet in her mouth; and she showed some slight but unequirocal signs of mortification when Maria, after all her trouble, would not eat it. Though she knows Maria and several other patients by name, she doe not seem to know her sister when alluded to as "Emily"; nor does she know the nurse who for some years has constantly attended to her, when alluded to by name or spoken of as " Nurse." That she does recognise her is evident from the fact that she obeys her better than anyone else.

She also knows some few objects by their names. She is nble to rub and dust the furmiture; and if told to dust a chair, she will not, as a rule, operate on a table, or vice vorsá, though 
she sometimes makes a mistuke. When bidden, she will go to the cupboard and get her bonnet, which she knows from all the others, though they are made of the same material. If her bonnet is not in its place, she will carefully examine all those in the capboard over and over again, and finally wander about the room looking for it.

Although she never makes any attempt to speak, she will, when given anything she likes, make a series of small courtesies, and will, when told to do so, clnp her hands, which, as before stated, she does in a very clumsy manner.

She possesses but little power of attention, and if shown anything she is as likely as not to go away before the exhibition is complete.

She does not exhibit to the slightest degree any tendency to imitate the actions or behaviour of others.

She is very fond of carrying a piece of string or cloth about in her hand, but, strange to say, she seems to care no more about coloured objects than about others. I never have been able to notice that she liked a piece of red or yellow cloth better then a black or white piece, nor have I been able to obtain any evidence that she had any idea of numbers.

Her memory does not seem very active; in fact it seems much less perfect in her than in her sister. Though I measured her head one day (a process she disliked), she did not keep out of my way, as her sister did, when I returned the following day with the instrument; nor did she seem to remember that $I$ had given her sweets. She seems to like music, but is not excessively fond of it.

I have ascertained that she is capable of experiencing, to some extent at least, the following emotions :-

Fear. She is very timid, and especially so of fire, and runs away from and screams at a lighted taper, though this is daily used to light the gas.

Affection she exhibits, to a small degree, towards several patients who take notice of her. She evidently likes to be with them in preference to others.

Rage she feels to a marked degree, biting and kicking the object of her anger.

She is revengeful, and will return to attack the offenders if prevented in her first attempt. After being angry, she is dull and sulky for some time, and mopes about, hanging her head. If scolded by the nurse, she shows signs of sorrow, and retires to stand in the corner.

She is possessed of a considerable degree of curiosity, and will inspect with interest anything new, and will direct tho attention of others to it. As an instance of this, I may mention that on one occasion the patients were to have their 
ter in the ward, the dining-ball being unavailablo; both she and her sister ran to some one who entefed the ward, and who lad not seen the preparations, and pointed out the teacups.

Pleasure she shows by smiling and by luughter, and by running about with her arms flexed at the elbows, shaking her hunds, and by uttering, from time to time, articulate but meaningless sounds.

She seems quite incapable of feeling sympathy, nor is slse known ever to have exhibited jealousy. She will show her mortification if she is not given sweets while others are, but she never shows any illwill to those more lucky than herself. So far as is known, she has never exhibited any sexual propensities whatover.

As may be supposed from the above account, attempts to teach her have not met with much success. She has learnt to feed herself with a spoon, though all attempts to make her clean in her habits have failed utterly. She allows the saliva to run from her mouth.

She sleeps well. When asleep she lies on her side, curled up with the knees applied to the abdomen and the hands upon the chest; in fact, she ussumes the foetal posture.

Her organs of the special senses are all in a perfectly healthy state.

Her heart and lungs are also quite healthy; her extremities are well supplied with blood. Digestion is satisfnctorily performed, and the excretory organs are healthy.

Her muscles are well developed; she is pretty strong; her limbs are thick and short.

Her sexual organs are matured; she menstruates with great regularity, and her mammæ are largely developed.

Emily G., ret. eleven years, was admitted when only four years old. Previously to admission she had had convulsions. Her general health had not been nearly so good as that of her sister. When admitted she was small for her age, and had a head very much flattened posteriorly, and of relatively smaller size than her sister's. All the cranial sutures were closed. She was unable to talk; nor could she feed herself. She allowed the saliva to run from her mouth, and passed her dejections under her.

She was nevertheless lively, and liked to be noticed, but was timid and afraid of strangers, like her sister. She was also passionate.

Her general health was not good, and she was subject to bronchial catarrh. During the first year of her life at this asylum she had several attacks of diarrhoen, and several times was under treatment for chest complaints. 
Sho however learnt to perform various acts, and could feed herself with a spoon, and became less dirty in her habits, and learned to understand much that was said to her.

Her health improved as she grew older. In 1873, that is, when she was five and a half years old, her head measured 139 in. in circumference. Since that time no great alteration has taken place in her habits or character.

Emily G. is now eleven years old. She is $3 \mathrm{ft}$. 6 inches in height, and weighs $44 \mathrm{lbs}$.

She bears a striking resemblance to her sister Anne.

Her head, like that of her sister, is very small.

The depression at the posterior part, described as being present in the head of Anne, is in her head much more marked (Fig. II. P.) Her palate is, like that of her sister, much arched, but not to so grear a degree. Her teeth are in good order; she is about a year behindhand in her dentition. Her nose is prominent and her chin recedes, but the face is much narrower, and her expression is less like that of a beaver than that of a mouse. Her eyes, unlike those of her sister, which are small and deep set, are prominent.

Her usual attitude is even more stooping than that of Anne.

'The measurements of her head are as follows:-

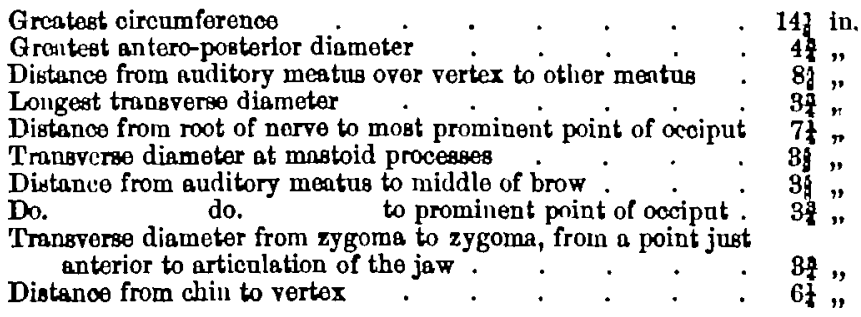

Her gait resembles that of her sister, but is altered to some extent by the presence of talipes varus of the right foot, for which $\operatorname{sh} \theta$ wears an instrument. Her movements are much more active and childlike.

Her general behaviour does not, however, grently differ from that of her sister, but she is more often alone, and is fond of nursing a doll, which Anne will not do.

She is able to say a few simple words. For example, she says " tata" when going to bed. She knows even more people by name than her sister, but it has not been possible to teach her to dust the furniture. She, however, knows her own clothes, and will put some of them on.

Her power of attention and her memory are much better than her sister's. 

sister.

She has no greater liking for bright colours than has her

As an instance of her dislike for strangers, and as an example of her power of memory, the following incident may be related. She had been taken to the store room to be weighed. She saw there an idiot, whom she sometimes, though not often, saw at a distance in the dining-hall. With him, when asked, she shook hands, but she screamed at the sight of the store keeper whom she never saw.

Like her sister, she has not the slightest idea of numbers, nor does she care about music; in fact she cares less about it than Anne does.

Affection she does not exhibit to so great a degree as her sister; nor is she so easily made angry, nor so violent when angry. She does not appear to be revengeful.

When scolded she is evidently sorry.

She smiles and laughs when pleased.

I have never noticed any evidence that she is capable of feeling compassion or sympathy.

Her mode of sleeping is exactly like that of her sister.

She is evidently scrofulous, and has had at various times enlargements of glands, \&c.

Her heart and lungs are normal, however, and her digestion fairly good.

The annexed Diagrams are half life-gize. They have been reduced from tracings obtained by accurately applying a strip of thin sheet-lead to the heads of the patients, in the same way as the cistometer is applied to the chest.

Fre. I-Represents the proflle viow of the head of Anne G. The hairy scalp begins at $B$. (The fiature from the tip of the nose to the ahin ware not obtained by means of the ciatometer, and have been simply added to complete the diagram. The positions of the eye and ear were obtained by aceurate measurement.)

Fia. II.-Represente the outline of the head of Emily G., showing the depression of it posterior part.

Fig. III.-Represunts the outline of the greater circumference of the head of Anne $G$. The letters $\triangle Q P$ corregpond to the points marked by the mame letters in Diagram $I$.

Fio. IV.-Represents the traoing obtained by applying the strip of lead to the head of Anne $G$, from ear to car over tlio rertex. 


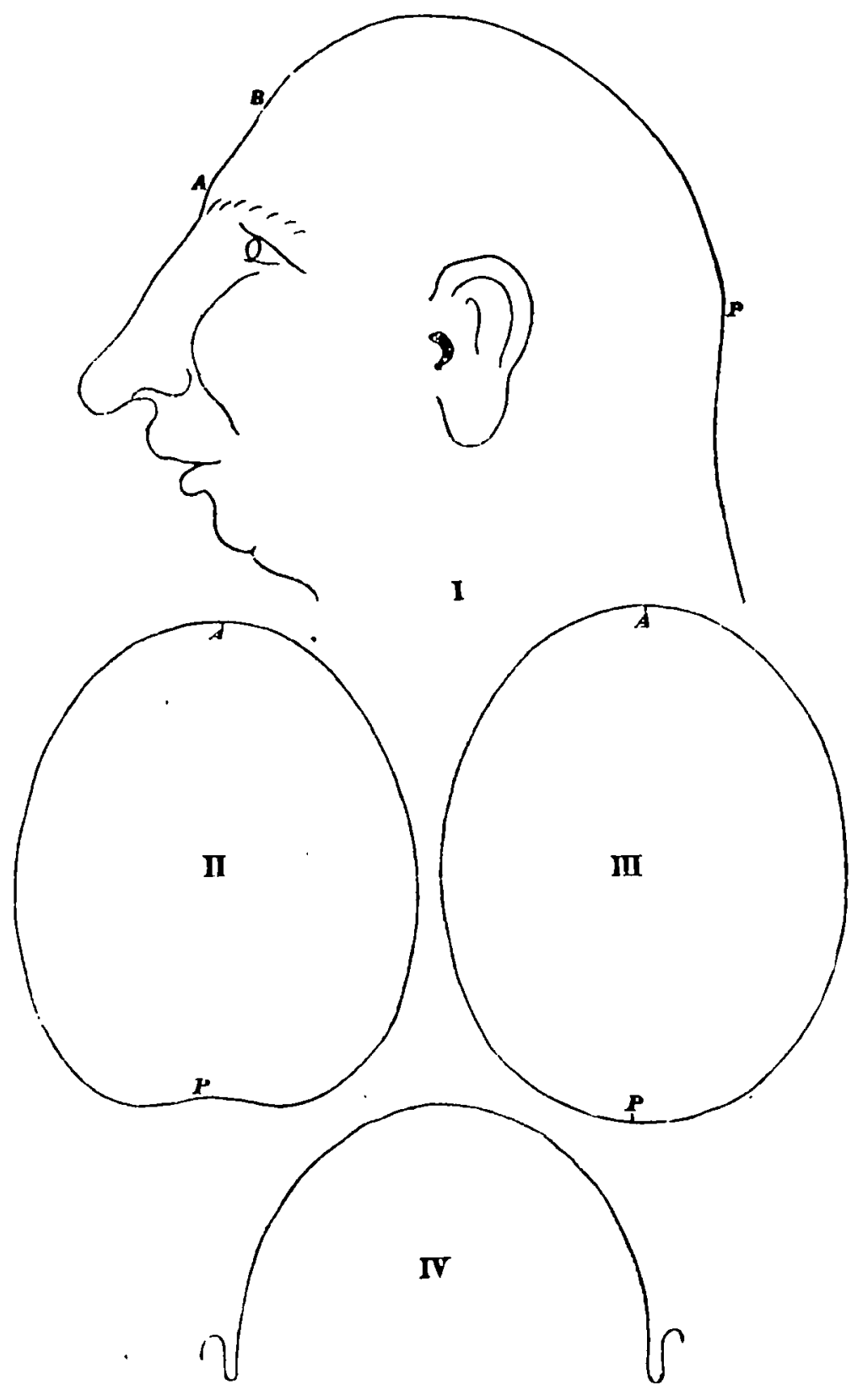

